\title{
Metabolic cold adaptation in the lugworm Arenicola marina: comparison of a North Sea and a White Sea population
}

\author{
A. M. Sommer*, H. O. Pörtner \\ Alfred-Wegener-Institut für Polar- und Meeresforschung, Ökophysiologie/Ökotoxikologie, Columbusstrasse, \\ 27568 Bremerhaven, Germany
}

\begin{abstract}
Mitochondrial mechanisms, which may define and adjust an organism's thermal tolerance window to the environmental temperature regime, were studied in 2 intertidal populations of the polychaete worm Arenicola marina (L.) from the North Sea (boreal) and the White Sea (subpolar). Adaptation to lower mean annual temperatures in the subpolar White Sea population $\left(4\right.$ vs $10^{\circ} \mathrm{C}$ in the North Sea) was reflected in a 2.4 times higher mitochondrial volume density in their muscle tissue. In White Sea worms acclimated to $6^{\circ} \mathrm{C}$, a 10 times higher cytochrome $c$-oxidase (CytOx) activity was seen and the activation energy $(E a)$ for the oxidation of cytochrome $C$ was reduced compared to boreal specimens acclimated to $11^{\circ} \mathrm{C}$. Moreover, mitochondria from White Sea lugworms were characterised by a 2.7 times higher succinate oxidation rate and reduced Ea under mitochondrial State 3 (phosphorylating) respiration at low temperatures, as well as a higher activity of NADP-dependent isocitrate dehydrogenase (IDH) compared to North Sea worms, even when acclimated to the same temperature of $11^{\circ} \mathrm{C}$. All these patterns reflect an overall rise in the capacity of aerobic energy production with cold adaptation. This explains the downward shift in the low critical temperature $(T \mathrm{c})$, beyond which anaerobic metabolism set in. However, the higher mitochondrial density is likely to have induced the rise in standard metabolic rate seen in the White Sea lugworms, causing a concomitant shift in the high $T_{\mathrm{c}}$ to a lower value. An increase in the Ea for the decarboxylation of isocitrate in White Sea specimens may help to minimise the increase in the standard metabolic rate induced by their higher mitochondrial density and capacity, at the expense of a higher thermal sensitivity of metabolism at higher temperatures.
\end{abstract}

KEY WORDS: Cold adaptation · Mitochondria $\cdot$ Aerobic capacity $\cdot$ Critical temperature $\cdot$ Arenicola marina Resale or republication not permitted without written consent of the publisher

\section{INTRODUCTION}

During the Pleistocene glaciations, and particularly during the maximum of the Würm Glaciation, the White Sea ceased to exist as a body of water, as its basin filled entirely with ice (Badyukov 1979). During these periods, the entire shelf of western Eurasia and the American Arctic was covered by ice and outlet glaciers even descended deep into the ocean. There-

*E-mail: asommer@awi-bremerhaven.de fore, shallow-water benthos was driven from not only the White Sea, but from the whole West-Eurasian Arctic (Nesis 1983). After the ice began to melt, glacial lakes were formed which thereafter began to connect with the ocean waters of the North Polar Sea. However, not until the second half of the Atlantic time period (about 5500 yr ago) was the White Sea finally free from ice in summer, and salinity reached marine levels (Badyukov 1979). Resettlement then occurred by animals from the Arctic deep sea and by species from more southern areas of the North Atlantic (Govberg 1974, Nesis 1983). 
For species from the south, settlement in the White Sea was accompanied by exposure to more extreme temperature conditions. Not only the mean annual temperature but also the minimum temperature experienced in winter was and still is lower. In addition, temperature changes in the short ice-free period of the White Sea are much faster than in the southern North Atlantic or in the North Sea (Zenkevitch 1963, Wolff 1983, Prandle \& Lane 1995). Therefore, successful settlement and reproduction under the new temperature conditions of the White Sea required adequate adaptation.

In ectothermic vertebrates, seasonal and latitudinal cold adaptation comprises a rise in aerobic capacity, which permits maintenance of cell functions in spite of low temperatures (for reviews see Guderley 1998, Pörtner et al. 1998). Associated processes are rising enzyme capacities (Crockett \& Sidell 1990, Guderley 1990), increased mitochondrial or capillary densities (Sisson \& Sidell 1987, Guderley \& Blier 1988, Ressel 2001), changes in mitochondrial structure (Gaebel \& Roots 1989, Archer \& Johnston 1991, St-Pierre et al. 1998) and/or alterations in membrane composition (Miranda \& Hazel 1996, Logue et al. 2000).

Comparatively little is known about the adjustment of aerobic metabolism during cold adaptation in marine invertebrates (Boyden 1972, Dahlhoff \& Somero 1993, Vetter \& Buchholz 1997). Sommer et al. (1997) and Sommer \& Pörtner (1999) studied the capacity and constraints of temperature adaptation in 2 populations (boreal and subpolar) of the lugworm Arenicola marina. It is thought that this polychaete, which is distributed over vast areas of the West Eurasian and American Arctic (Wesenberg-Lund 1953, HartmannSchröder 1971), migrated into the White Sea from temperate Atlantic waters. Therefore, the worm is a suitable model to study the adaptation of marine, eurythermal invertebrates not only to harsh winter conditions (seasonal cold) but also to life at lower mean annual temperatures (latitudinal cold). A low and a high critical temperature $\left(T_{\mathrm{c}}\right)$ were identified that are characterised by the onset of anaerobic metabolism (Sommer et al. 1997). As a result of the progressively insufficient capacity of ventilatory or circulatory mechanisms (see Pörtner 2001 for review), the energy demand of the lugworm could not be met by an adequate oxygen supply, and additional anaerobic energy production was thus required. Comparisons of North Sea with White Sea lugworms as well as of winter with summer animals revealed that latitudinal or seasonal temperature adaptations led to a more or less parallel shift in both TCS (Sommer et al. 1997).

The present study was designed to identify potential mechanisms that cause an adjustment in thermal tolerance to the environmental temperature regime.
Lugworms from the North and White Seas were compared with respect to the rate of aerobic metabolism, the density and functional capacity of mitochondria in their muscle tissue, and the activities and thermal sensitivities of key enzymes of aerobic metabolism.

In their natural environment, the boreal North Sea lugworms are rarely exposed to ice cover in January or February, whereas in summer the sediment can heat up to $25^{\circ} \mathrm{C}$ at those depths in which their burrows are situated. The mean annual surface water temperature is $10^{\circ} \mathrm{C}$. Depending on temperature and season, the maximum depths of their burrows vary, ranging between $15 \mathrm{~cm}$ in summer and $70 \mathrm{~cm}$ in winter. The temperature of the White Sea near Kartesh is on average $4^{\circ} \mathrm{C}$, and it is ice-covered for about 6 mo each year (Howland et al. 1999), when the temperature in the sediment can drop to $-5^{\circ} \mathrm{C}$ (Kolyakina 1980). During the short summer period the sediment temperature can reach $18^{\circ} \mathrm{C}$ (Sommer 1998, Howland et al. 1999). Because of a thick layer of clay and rocks below the sandy sediment, White Sea worms are restricted to burrows with a maximum depth of 10 to $15 \mathrm{~cm}$.

\section{MATERIALS AND METHODS}

Lugworms. Specimens of Arenicola marina were collected from 1996 to 1999 from intertidal flats of the North Sea near Dorum, Germany (5342' N, 8³5' E) (hereafter called boreal or North Sea lugworms), and of the White Sea near Kartesh, Russia (66 $20.8^{\prime} \mathrm{N}$, $33^{\circ} 35.8^{\prime} \mathrm{E}$ ) (hereafter called subpolar or White Sea lugworms) near the low-water line. The body weight of the boreal worms was 1 to $8 \mathrm{~g}$, that of the subpolar worms 1 to $4 \mathrm{~g}$. Despite the lower mean annual temperatures in the environment of the subpolar lugworms, late summer was chosen for their collection, so that surface water temperatures were similar in both areas. Histological studies were performed on freshly collected individuals. Prior to physiological measurements, the lugworms were kept in the laboratory for up to $5 \mathrm{wk}$ in aquaria filled with well-aerated natural brackish seawater ( 22 to $24 \%$ ) and a 5 to $10 \mathrm{~cm}$ bottom layer of sand. In accordance with the ambient water temperatures during collection, both North and White Sea worms were kept at $11 \pm 1^{\circ} \mathrm{C}$, except for subpolar worms collected in 1996 for the measurement of whole-organism metabolic rate and measurement of cytochrome $C$-oxidase, which were kept at $6 \pm 0.5^{\circ} \mathrm{C}$ because of problems with the cooling-room facilities.

Oxygen consumption measurements of whole worms. The influence of temperature on metabolic rate was quantified by an analysis of oxygen consumption. Measurements were performed in the dark with worms inhabiting slightly bent Plexiglas tubes filled 
with heat-sterilised, natural sediment. The water flow through the tube was set between 2 and $3 \mathrm{ml} \mathrm{min}^{-1}$ by a peristaltic pump, Perimax 12 (Spetec). Oxygen tension was monitored continuously by a Clark-type oxygen electrode (Eschweiler). The experiments started at $10^{\circ} \mathrm{C}$ and temperature was lowered to $-3^{\circ} \mathrm{C}$ or was elevated to $25^{\circ} \mathrm{C}$ in a stepwise procedure (see Fig. 1). After an acclimation period of up to $12 \mathrm{~h}$ for each temperature, oxygen consumption was recorded and the mean rate was calculated for a period of $3 \mathrm{~h}$. Values were expressed as $\mu \mathrm{mol} \mathrm{O}_{2} \mathrm{~h}^{-1} \mathrm{~g}^{-1}$ fresh wt standardised to an individual of $1 \mathrm{~g}$ by means of an allometric factor of 0.77 (Krüger 1964). To prevent errors due to oxygen uptake by bacteria or the $\mathrm{P}_{\mathrm{O}_{2}}$-sensor, oxygen concentrations in the water were monitored at each temperature in experiments with tubes containing sediment only. Background oxygen consumption was less than $5 \%$ of the rates obtained with the experimental worms.

Isolation of mitochondria. For the study of coupled mitochondria from body-wall tissue, specimens of both populations were acclimated to $11^{\circ} \mathrm{C}$. A modified buffer according to Schroff \& Schöttler (1977) was used for mitochondria isolation. The buffer contained $550 \mathrm{mmol} \mathrm{l}^{-1}$ glycine; $250 \mathrm{mmol} \mathrm{l}^{-1}$ sucrose; $4 \mathrm{mmol} \mathrm{l}^{-1}$ EDTA (ethylenedinitrilo-tetraacetic acid); $40 \mathrm{mmol} \mathrm{l}^{-1}$ Tris-HCl (Tris[hydroxymethyl]aminomethane hydrochloride), $\mathrm{pH}_{20^{\circ} \mathrm{C}} 7.5 ; 1 \mu \mathrm{g} \mathrm{ml}^{-1}$ aprotinin; and $1 \% \mathrm{w} / \mathrm{v}$ BSA (bovine serum albumine, Fraction $V$, essentially fatty acid-free). After decapitation of the worms, their tails were removed and longitudinal incisions were made in the body wall musculature to open them. The digestive tracts and gonads were removed. The bodywall tissues of 2 to 4 individuals were pooled, washed in cold seawater and placed in $40 \mathrm{ml}$ ice-cold buffer. A total of $2 \mathrm{~g}$ fresh weight was cut into small pieces and homogenised using a loose-fitting Teflon pestle and glass tube (0.7 mm space) with a Heidolph RZR 1 drive and speed controller (Heidolph). Final homogenisation took place with a Teflon pestle and glass tube of $0.5 \mathrm{~mm}$ space with 3 to 4 passes. The resulting homogenate was centrifuged at $1300 \times g$ for $8 \mathrm{~min}\left(0^{\circ} \mathrm{C}\right)$ to separate cellular debris. The supernatant was collected and the pellet resuspended in $10 \mathrm{ml}$ buffer for a second spin $\left(1300 \times g, 8 \mathrm{~min}, 0^{\circ} \mathrm{C}\right)$. Thereafter both supernatants were pooled and a third centrifugation step $\left(10000 \times g, 15 \mathrm{~min}, 0^{\circ} \mathrm{C}\right)$ yielded the mitochondrial pellet which was resuspended in about $2 \mathrm{ml}$ buffer.

Mitochondrial respiration. To study the thermal sensitivity of mitochondrial energy production and oxygen demand, for comparison to the whole worm response, mitochondrial oxygen consumption was assayed under phosphorylating (State 3) and nonphosphorylating (State 4) conditions. Measurements were performed at temperatures between -1 and $+32^{\circ} \mathrm{C}$ using a Clark-type oxygen electrode in a temperature-controlled respiration chamber (Eschweiler) under continuous stirring; $200 \mu$ of the mitochondrial suspension and $20 \mu \mathrm{l}$ of a BSA solution (50\% w/v) were added to $780 \mu \mathrm{l}$ of assay medium (550 $\mathrm{mmol}^{-1}$ glycine, $250 \mathrm{mmol} \mathrm{l}^{-1}$ sucrose, $20 \mathrm{mmol} \mathrm{l}{ }^{-1}$ Tris- $\mathrm{HCl}\left(\mathrm{pH}_{20^{\circ} \mathrm{C}} 7.5\right)$, $4 \mathrm{mmol} \mathrm{l}^{-1}$ EDTA, $5 \mathrm{mmol} \mathrm{l}{ }^{-1} \mathrm{~K}_{2} \mathrm{HPO}_{4}, 3 \mathrm{mmol} \mathrm{l}{ }^{-1} \mathrm{MgCl}_{2}$ $6 \mathrm{H}_{2} \mathrm{O}, 1 \mu \mathrm{g} \mathrm{ml} \mathrm{m}^{-1}$ aprotinin) containing $5 \mu \mathrm{mol} \mathrm{l}^{-1} \mathrm{Ap} 5 \mathrm{~A}$, an inhibitor of myokinase, and up to $10 \mathrm{mmol}^{-1}$ succinate as substrate for maximum activity. After monitoring State 2 respiration rate, ADP $\left(125 \mu \mathrm{mol} \mathrm{l}^{-1}\right)$ was added with a Hamilton syringe to determine the rate of State 3 respiration. When all ADP had been phosphorylated, the rate of State 4 respiration was determined for about $5 \mathrm{~min}$, before oligomycin, an inhibitor of mitochondrial $\mathrm{F}_{0} \mathrm{~F}_{1}$-ATPase was added to a concentration of $2 \mu \mathrm{g} \mathrm{ml} \mathrm{m}^{-1}$. State 4 respiration after the addition of oligomycin (State 4 ol) reflects oxygen demand owing to proton leakage and oxygen radical production of isolated mitochondria. It indicates to what extent substrates and oxygen are used without coupling with ATP synthesis (Brand et al. 1994). Respiratory control ratios were determined by dividing State 3 by State 4 respiration rates before (RCR [Respiratory Control Radio]: Estabrook 1967) or after the addition of oligomycin (RCRol: Pörtner et al. 1999) to provide information about the efficiency of energy production in relation to oxygen demand (van Dam \& Wiechmann 1979). Effective ADP/O ratios were calculated as nanomoles ADP added divided by nanoatoms oxygen utilised during State 3 respiration (Estabrook 1967). Preliminary examinations revealed that the addition of $5 \mu \mathrm{M}$ rotenone had no influence on respiration rates or the ADP/O ratio. We therefore refrained from further adding this inhibitor of Complex I of the respiratory chain.

Oxygen solubility in the assay medium at different temperatures was adopted from Johnston et al. (1994) taking changes in atmospheric pressure into consideration. Protein concentrations were determined by the Biuret method (Kresze 1988) using BSA as standard.

Enzyme activities. The activity of the mitochondrial marker enzyme cytochrome $C$-oxidase $\left(\mathrm{CytOx}_{\mathrm{i}} \mathrm{EC}\right.$ 1.9.3.1.) was assayed according to a method modified from Hand \& Somero (1983). Body wall tissues of 3 to 7 animals $(\sim 1.5 \mathrm{~g})$ were pooled and washed in ice-cold extraction buffer $\left(20 \mathrm{mmol} \mathrm{l}^{-1}\right.$ potassium phosphate buffer, $\mathrm{pH}_{20^{\circ} \mathrm{C}}$ 7.4). The tissue was minced and homogenised using a Teflon pestle and glass tube (see earlier). The homogenate was centrifuged twice at $2000 \times g$ for $15 \mathrm{~min}$ and the supernatants from both centrifugation steps were pooled. For reversible acid precipitation of mitochondrial proteins, $1 \mathrm{~mol} \mathrm{l}^{-1}$ acetic acid was added to the supernatant $\left(\mathrm{pH}_{0^{\circ} \mathrm{C}}\right.$ 5.6). Activity of CytOx was determined in the pellet after a third 
centrifugation at $5000 \times g$ for $15 \mathrm{~min}$. The assay was performed with this resuspended precipitate. The reaction mixture consisted of $200 \mathrm{mmol} \mathrm{l}^{-1}$ potassium phosphate buffer $\left(\mathrm{pH}_{20^{\circ} \mathrm{C}} 6.0\right)$ with $1 \mathrm{mmol} \mathrm{l}^{-1}$ EDTA and $0.2 \%$ reduced cytochrome $c$. The reaction was initiated by adding the enzyme. Oxidation of reduced cytochrome $c$ was monitored by following the decrease in absorption at $550 \mathrm{~nm}$ at controlled temperatures between 0 and $45^{\circ} \mathrm{C}$ (Spectrophotometer DU 7400, Beckman Instruments).

A method by Sugden \& Newsholme (1975) was used to determine the activity of NADP-dependent isocitrate dehydrogenase (IDH; EC 1.1.1.42) in homogenates prepared from muscle tissue. This enzyme is supposed to play important roles in the regulation of flux through the citric acid cycle and the mitochondrial proton leakage (Urich 1990, Sazanov \& Jackson 1994). Information on the influence of temperature on IDH may therefore explain parts of the thermal sensitivity of mitochondrial energy production. Approximately $300 \mathrm{mg}$ of body-wall tissue were carefully rinsed with cold seawater and blotted dry with tissue paper before they were minced and homogenised in $5 \mathrm{ml}$ ice-cold

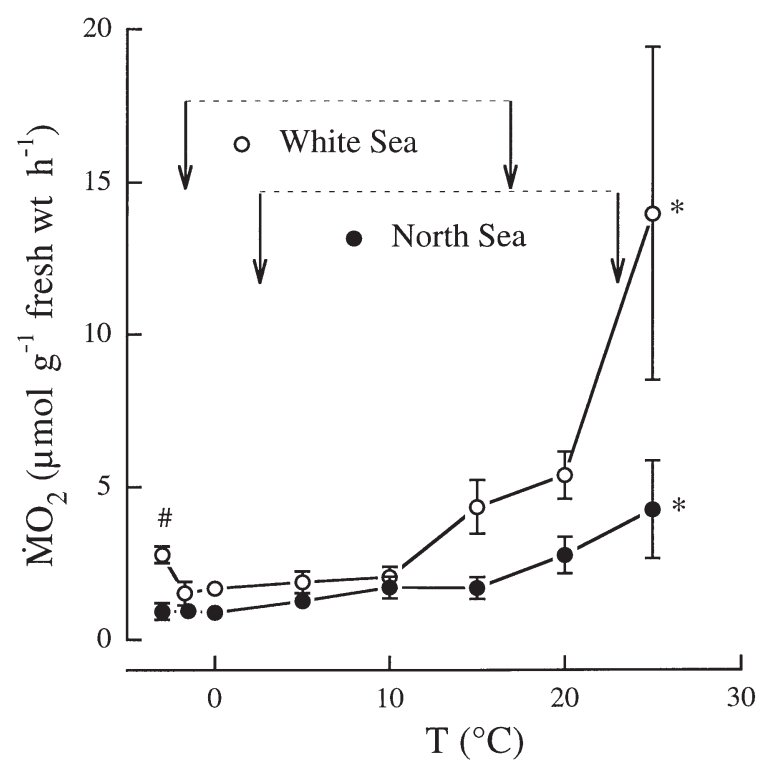

Fig. 1. Arenicola marina. Metabolic rate, as oxygen consumption ( $\mu \mathrm{mol} \mathrm{g}{ }^{-1}$ fresh $w t \mathrm{~h}^{-1}$ ) of lugworms collected in summer from the North Sea (maintenance temperature $11^{\circ} \mathrm{C}$ ) or White Sea $\left(6^{\circ} \mathrm{C}\right)$ after $12 \mathrm{~h}$ acclimation to different temperatures. Oxygen consumption differed significantly between the 2 populations $\left(\mathrm{p}=0.002\right.$; mean $\pm \mathrm{SE}_{i} \mathrm{n}$ ranged between 4 and 8 (14) in North Sea and between 3 and 8 (13) in White Sea lugworms (numbers 14 and 13 in parentheses are numbers at $10^{\circ} \mathrm{C}$, where both temperature series overlapped: (see 'Materials and methods'); $*$ : Significantly different from value at $10^{\circ} \mathrm{C}_{i}$ \#: significantly different from value at $-1.7^{\circ} \mathrm{C}$; arrows indicate high and low critical temperatures $(T \mathrm{CS})$ according to Sommer et al. (1997) extraction buffer using a Teflon pestle and glass tube (see earlier). The latter consisted of $50 \mathrm{mmol} \mathrm{l}^{-1}$ triethanolamine, $1 \mathrm{mmol} \mathrm{l}^{-1}$ EDTA, $2 \mathrm{mmol} \mathrm{l}^{-1} \mathrm{MgCl}_{2}$ and $30 \mathrm{mmol} \mathrm{l}^{-1}$ mercaptoethanol adjusted with $\mathrm{KOH}$ to $\mathrm{pH}_{20^{\circ} \mathrm{C}}$ 7.5. Mitochondria were ruptured by sonication for $2 \times 25 \mathrm{~s}$ before the homogenate was centrifuged for $10 \mathrm{~min}$ at $600 \times g$ to withdraw cellular debris. Activity in the supernatant was assayed by following changes in absorption at $\lambda=339 \mathrm{~nm}$. Temperature conditions ranged from 0 to $30^{\circ} \mathrm{C}$ (Spectrophotometer DU 7400, Beckman Instruments). The assay medium consisted of 70 mmol $\mathrm{l}^{-1}$ Tris- $\mathrm{HCl}\left(\mathrm{pH}_{20^{\circ} \mathrm{C}} 7.5\right)$ with $1 \mathrm{mmol} \mathrm{l^{-1 }}$ $\mathrm{MnCl}_{2}, 8 \mathrm{mmol} \mathrm{l}^{-1} \mathrm{MgCl}_{2}$ and $2.5 \mathrm{mmol} \mathrm{l}^{-1} \mathrm{NADP}$. The reaction was initiated by adding $22.5 \mathrm{mmol} \mathrm{l}^{-1}$ citrate and $3 \mathrm{mmol} \mathrm{l}^{-1} \mathrm{D}, \mathrm{L}$-isocitrate to the assay.

Electron microscopy. Sommer et al. (1997) suggested that the adjustment of mitochondrial density is involved in setting TCS in lugworms. Histological analyses of the body-wall musculature should verify this hypothesis. The body-wall musculature was excised from freshly collected individuals. Head and tail were dissected, the worms were opened completely and gonads as well as digestive tracts removed. The body-wall tissue was cut into cubes of about $1 \mathrm{~mm}^{3}$ with a sharp blade. Samples were fixed by immersion in $0.1 \mathrm{~mol} \mathrm{l}^{-1}$ sodium phosphate buffer containing $2.5 \%$ v/v glutaraldehyde $(\mathrm{pH}=7.2)$. Fixation was allowed to proceed for $30 \mathrm{~min}$. Tissue was washed directly after fixation and periodically during storage with cold sodium phosphate buffer $\left(0.1 \mathrm{~mol} \mathrm{l}^{-1}\right)$ without glutaraldehyde. Samples were stored at $4^{\circ} \mathrm{C}$ in the dark until further analysis. Post-fixation was carried out with phosphate buffer containing $2 \%$ w/v osmium tetroxide, followed by dehydration in acetone at increasing concentrations (40 to $100 \% \mathrm{v} / \mathrm{v}$ ) and immediate embedding in epoxide resin. Ultrathin sections (50 to $70 \mathrm{~nm}$ ) were stained with uranyl acetate for $6 \mathrm{~min}$, and subsequently with lead citrate (Reynolds 1963) for $4 \mathrm{~min}$. Sections were analysed on 200-mesh grids with a transmission electron microscope, CEM 902 (Carl Zeiss). Mitochondrial volume densities $\left(V_{\mathrm{M}}\right)$ were calculated using the point-sampling method in randomly chosen cross-sections of muscle cells (Plattner \& Zingsheim 1987):

$V_{\mathrm{M}}(\%)=\frac{\text { No. of points covering the mitochondria } \times 100}{\text { Total no. of points covering the tested muscle tissue }}$

A mean volume density was then calculated for each population from a total sample size of 93 muscle crosssections based on 26 tissue preparations of 6 lugworms.

Calculations. All data were checked for outliers beyond the $r(99)$ limits of an r-distribution ( $\mathrm{r}_{\mathrm{A}}>\mathrm{r}$ [99]) using Nalimov's test (Noack 1980). Rates of enzyme activities and mitochondrial respiration rates were 
plotted as a function of temperature. Analysis of variance (ANOVA) or covariance (ANCOVA) and the posthoc Student-Newman-Keuls test were used to assess the effect of temperature or population origin. Arrhenius break temperatures $\left(T_{\mathrm{AB}}\right)$ were determined by comparing sequential linear regressions and selecting 2 intersecting lines when the sum of squares was minimal and regressions were significantly different. The $T_{\mathrm{AB}}$ was defined by midpoint approximation (Yeager \& Ultsch 1989). For linear regressions with a break point, statistical significance of differences between the populations was analyzed with an F-test according to Nickerson et al. (1989). Activation energy (Ea) for each mitochondrial or enzyme preparation was calculated according to Eq. (2) where $k_{1}$ and $k_{2}$ are the specific reaction rates at the lower or higher temperature $\left(T_{1}\right.$, $T_{2}$ ) and $R$ is the general gas constant (Segal 1976):

$$
E a=R \times T_{1} \times T_{2} \times \ln \left(k_{2} / k_{1}\right) \times\left(T_{2}-T_{1}\right)^{-1}
$$

A paired Student's $t$-test was used to compare Ea values above and below $T_{\mathrm{AB}}$ of the same mitochondrial or enzyme preparation and an unpaired $t$-test to compare Ea values between populations. Statistical significance of differences was tested at the $\mathrm{p} \leq 0.05$ level. Data are given as means $\pm \mathrm{SE}$.

\section{RESULTS}

\section{Temperature-dependence of metabolic rate}

The influence of temperature on metabolic rate was investigated in whole worms during exposure to temperatures from -3 to $25^{\circ} \mathrm{C}$, starting from different acclimation temperatures for the 2 populations. When tem- perature was lowered in a stepwise procedure from 10 to $-3^{\circ} \mathrm{C}$, oxygen consumption decreased in North Sea individuals acclimated to $11^{\circ} \mathrm{C}$ from $1.71 \pm 0.36 \mu \mathrm{mol}$ $\mathrm{O}_{2} \mathrm{~h}^{-1} \mathrm{~g}^{-1}$ fresh wt $(\mathrm{n}=14)$ to a minimum value of $0.93 \pm 0.28 \mu \mathrm{mol} \mathrm{O} \mathrm{h}^{-1} \mathrm{~g}^{-1}$ fresh wt $(\mathrm{n}=5)$ (Fig. 1). With rising temperatures, oxygen consumption increased by a mean $Q_{10}$ of 1.67 (Table 1) to $4.25 \pm 1.60 \mu \mathrm{mol} \mathrm{O} \mathrm{O}_{2} \mathrm{~h}^{-1}$ $\mathrm{g}^{-1}$ fresh wt $(\mathrm{n}=4)$ at $25^{\circ} \mathrm{C}$ (Fig. 1). However, the increase in metabolic rate with rising temperature was not uniform. $Q_{10}$ values showed a minimum value of 0.96 at temperatures between 10 and $15^{\circ} \mathrm{C}$, indicating that metabolic rate was relatively insensitive to temperature changes around the in situ acclimation temperature. Lugworms from the White Sea also displayed increased oxygen consumption rates with rising temperatures, from $1.51 \pm 0.39 \mu \mathrm{mol} \mathrm{O} \mathrm{O}^{-1} \mathrm{~g}^{-1}$ fresh wt ( $\mathrm{n}=3$ ) at $-1.7^{\circ} \mathrm{C}$ to $13.94 \pm 5.46 \mu \mathrm{mol} \mathrm{O} \mathrm{h}^{-1} \mathrm{~g}^{-1}$ fresh wt (n $=4$ ) at $25^{\circ} \mathrm{C}$ (Fig. 1). The $Q_{10}$ increased with rising temperatures from a low of 1.18 between 5 and $10^{\circ} \mathrm{C}$ to a maximum of 6.71 between 20 and $25^{\circ} \mathrm{C}$. The temperature range characterised by the low $Q_{10}$ shifted to lower values in these worms in accordance with the in situ acclimation temperature of $6^{\circ} \mathrm{C}$. An anomaly was seen in White Sea worms at low temperatures. When temperature was reduced from -1.7 to $-3^{\circ} \mathrm{C}$, oxygen consumption did not decrease as expected from the reaction velocity-temperature relationship, but even showed a significant rise to $2.79 \pm 0.28 \mu \mathrm{mol} \mathrm{O} \mathrm{O}^{-1} \mathrm{~g}^{-1}$ fresh wt $(n=7)$. Such a rise in oxygen consumption rate was not observed in animals from the North Sea at low temperatures. Therefore, White Sea worms had significantly higher oxygen consumption rates at $-3^{\circ} \mathrm{C}$ compared with boreal lugworms. The oxygen consumption rates at high temperatures were also significantly higher in subpolar than in boreal worms.

Table 1. Arenicola marina. Values of $Q_{10}$ and Arrhenius activation energies, Ea (kJ mol ${ }^{-1}$ ) for whole-organism oxygen consumption ( $\mathrm{n}=7$ ), mitochondrial respiration ( $\mathrm{n}=5$ to 8 ) in States 3 (phosphorylating), 4 (non-phosphorylating) and $4 \mathrm{ol}$ (State 4 after addition of oligomycin) and for the reactions catalyzed by cytochrome $c$-oxidase (CytOx; $\mathrm{n}=5$ to 7 ) and NADP-dependent isocitrate dehydrogenase (NADP-IDH; $\mathrm{n}=5$ to 6 ) in North and White Sea lugworms. Values are means $\pm \mathrm{SE}$

\begin{tabular}{|c|c|c|c|c|c|}
\hline & \multirow[t]{2}{*}{$T$ range $\left({ }^{\circ} \mathrm{C}\right)$} & \multicolumn{2}{|c|}{ North Sea } & \multicolumn{2}{|c|}{ White Sea } \\
\hline & & $Q_{10}$ & $E a$ & $Q_{10}$ & $E a$ \\
\hline Whole worm & $-1.7-25$ & $1.67 \pm 0.29$ & $27.95 \pm 13.32$ & $2.84 \pm 0.93$ & $55.48 \pm 21.36$ \\
\hline State 3 & $\begin{array}{c}0-5 \\
11-32\end{array}$ & $\begin{array}{l}4.24 \pm 1.16 \\
1.47 \pm 0.07\end{array}$ & $\begin{array}{r}120.55^{\mathrm{a}} \pm 8.75 \\
12.83 \pm 5.36\end{array}$ & $\begin{array}{l}2.11 \pm 0.56 \\
1.60 \pm 0.16\end{array}$ & $\begin{array}{c}63.81^{\mathrm{a}, \mathrm{b}} \pm 16.94 \\
18.03 \pm 2.55\end{array}$ \\
\hline State 4 & $0-32$ & $2.41 \pm 0.25$ & $62.77 \pm 3.75$ & $2.15 \pm 0.15$ & $60.90 \pm 4.49$ \\
\hline State $4 \mathrm{ol}$ & $\begin{array}{l}0-5 \\
5-32 \\
0-32\end{array}$ & $\begin{array}{l}4.06 \pm 1.73 \\
2.07 \pm 0.19\end{array}$ & $\begin{array}{c}116.23 \pm 35.63 \\
43.75 \pm 2.29\end{array}$ & $2.19 \pm 0.19$ & $61.22^{\mathrm{b}} \pm 1.94$ \\
\hline CytOx & $0-45$ & $1.77 \pm 0.13$ & $39.75 \pm 5.06$ & $1.23 \pm 0.02^{\mathrm{b}}$ & $14.01 \pm 1.18^{\mathrm{b}}$ \\
\hline NADP-IDH & $3-31$ & $2.53 \pm 0.13$ & $65.38 \pm 4.36$ & $3.49 \pm 0.50$ & $83.35 \pm 9.36$ \\
\hline
\end{tabular}




\section{Mitochondrial density, capacity and thermal sensitivity}

Sommer et al. (1997) suggested that the adjustment of mitochondrial density is involved in setting the $T_{\mathrm{C}}$ values in lugworms. Histological analyses of the bodywall musculature actually demonstrated that mitochondrial density is significantly higher in White Sea than in North Sea specimens collected at similar in situ temperatures of about $12^{\circ} \mathrm{C}$ (Table 2). No differences were found in the size of mitochondria.

When mitochondria were prepared from worms acclimated to the same temperature of $11^{\circ} \mathrm{C}$, significantly higher maximal rates of succinate oxidation (nmol O min ${ }^{-1} \mathrm{mg}^{-1}$ protein) were seen in preparations from subpolar animals at all assay temperatures than in preparations from boreal lugworms (Fig. 2). For example, maximal oxidation capacity in mitochondria at $11^{\circ} \mathrm{C}$ was $3.96 \pm 0.58 \mathrm{nmol} \mathrm{O} \mathrm{min}^{-1} \mathrm{mg}^{-1}$ mitochondrial protein $(n=7)$ in North Sea animals and $12.83 \pm$

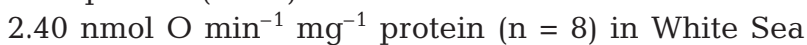
worms. The significantly lower Ea of State 3 respira-

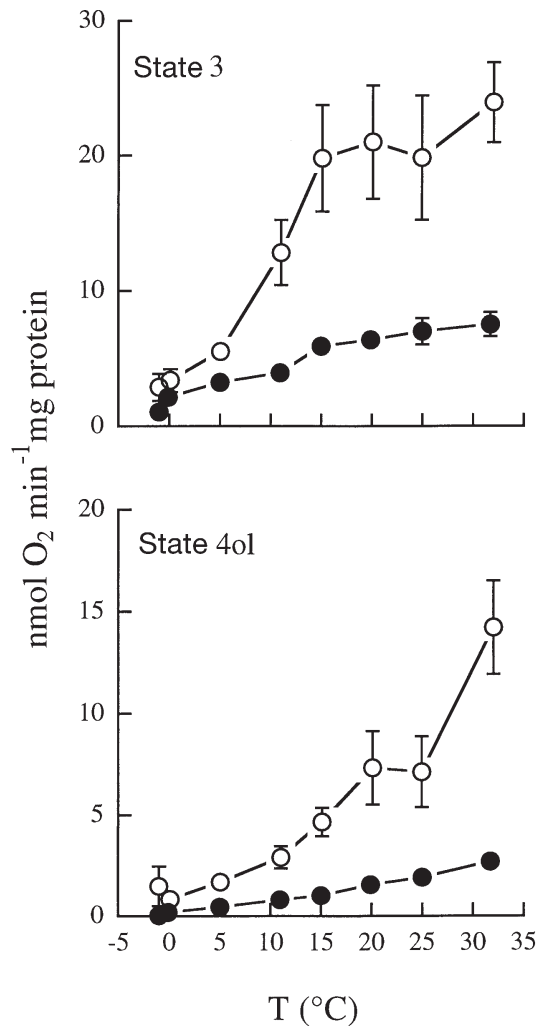

Fig. 2. Arenicola marina. Temperature dependence of mitochondrial respiration rates determined in North $(\bullet)$ and White (O) Sea lugworms acclimated to $11^{\circ} \mathrm{C}$. Temperatures varied between -1 and $32^{\circ} \mathrm{C}$. Respiration rates in all States differed significantly between the 2 populations. Data are means $\pm \mathrm{SE}$;

$$
\mathrm{n}=5 \text { to } 8
$$

Table 2. Arenicola marina. Mitochondrial volume density (\%); this differed significantly in body-wall muscles of populations from the North and White Seas both collected at a temperature of $12^{\circ} \mathrm{C}$. Values are means $\pm \mathrm{SE}$

\begin{tabular}{|lc|}
\hline North Sea (boreal) & White Sea (subpolar) \\
\hline $1.84 \pm 0.41(\mathrm{n}=27)$ & $4.47 \pm 0.52(\mathrm{n}=66)$ \\
\hline
\end{tabular}

tion in White Sea lugworms (Table 1) led to reduced factorial differences between White and North Sea mitochondria at low temperatures.

In both populations, the increase in mitochondrial respiration (nmol $\mathrm{O} \mathrm{min}{ }^{-1} \mathrm{mg}^{-1}$ protein) in State 3 was not exponential within the temperature range studied (Fig. 2). Arrhenius plots of State 3 respiration rates (Fig. 3) showed discontinuities between 5 and $11^{\circ} \mathrm{C}$,

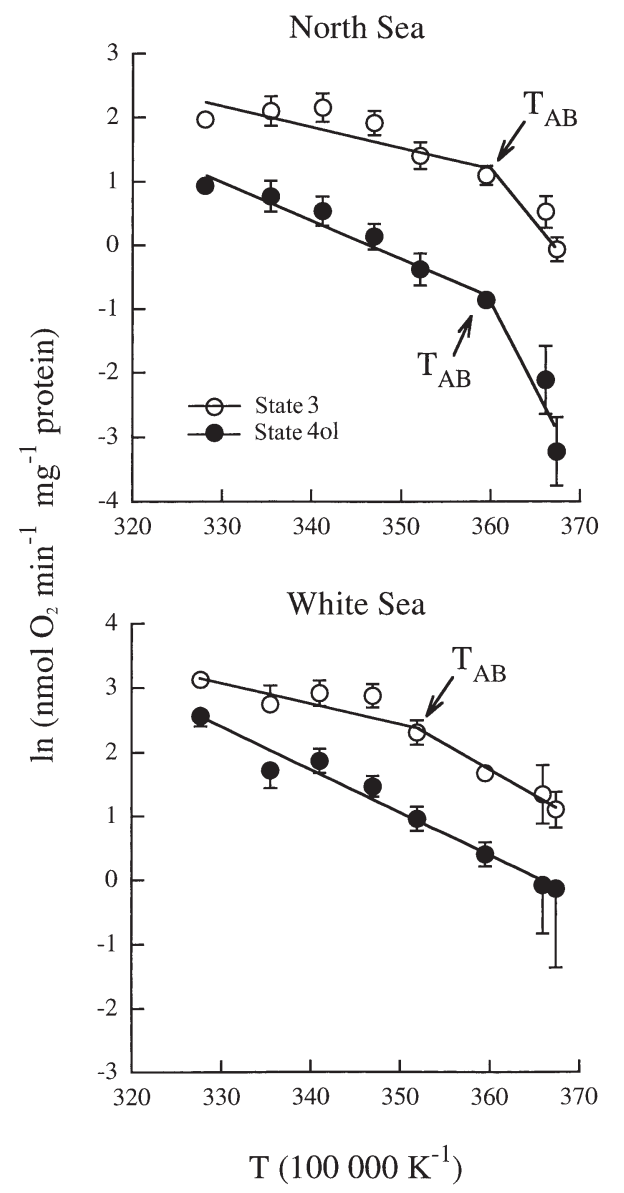

Fig. 3. Arenicola marina. Non-linear Arrhenius plots (ln respiration rate vs inverse temperature) of State 3 (O) or State 4 ol (•) respiration rates, indicating abrupt changes in thermal sensitivity. Slopes reveal Arrhenius activation energies (Ea: Table 1). State 3 respiration rates differed significantly between the 2 populations. Data are means $\pm \mathrm{SE}_{;} \mathrm{n}=5$ to 8 ; $T_{\mathrm{AB}}=$ Arrhenius break temperature 
with a transition to significantly lower values of $Q_{10}$ and $E a$ above $T_{\mathrm{AB}}$ (Table 1). The linear regression analysis indicates that, in White Sea worms, $T_{\mathrm{AB}}$ occurred at higher temperatures than in boreal animals (Fig. 3). However, the low number of data points below $T_{\mathrm{AB}}$ does not allow clear distinction between the $T_{\mathrm{AB}}$ values of both populations. Also, since both $T_{\mathrm{AB}}$ values are close to or even below the acclimation temperature of $11^{\circ} \mathrm{C}$, they most probably do not reflect thermal disturbance of mitochondrial functions, but rather a change in temperature-dependent regulation of respiratory capacities. Below the $T_{\mathrm{AB}}$, White Sea worms displayed significantly lower Ea values than North Sea specimens.

RCR values after the addition of oligomycin varied significantly with assay temperature and population (Fig. 4). In mitochondria of North Sea worms, RCRol values decreased from $11.43 \pm 3.09$ at $0^{\circ} \mathrm{C}$ to $2.70 \pm$ 0.19 at $32^{\circ} \mathrm{C}$. In mitochondria prepared from subpolar animals RCRol values were lower and decreased from $4.24 \pm 0.76$ at $0^{\circ} \mathrm{C}$ to $2.01 \pm 0.24$ at $32^{\circ} \mathrm{C}$. $\mathrm{RCR}$ values
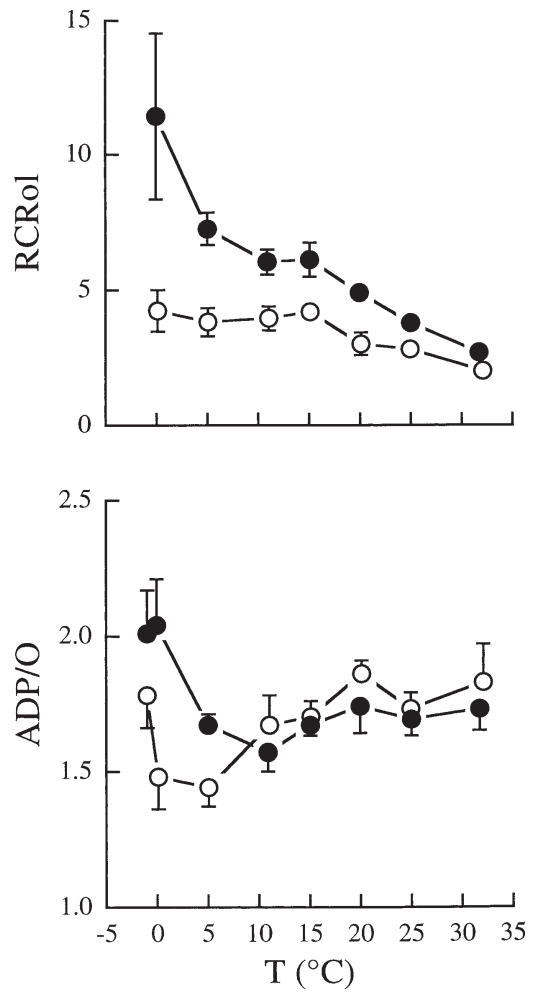

Fig. 4. Arenicola marina. Temperature-dependence of the ratios of State 3 respiration (induced by ADP phosphorylation) and State 4 respiration after addition of oligomycin (induced by proton leakage, RCRol) and of the oxygen consumed per phosphorylated ADP (ADP/O) in North $(\bullet)$ and White $(0)$ Sea lugworms acclimated to $11^{\circ} \mathrm{C}$. Temperatures varied between -1 and $32^{\circ} \mathrm{C}$. RCRol ratio differed significantly between the 2 populations. Data are means $\pm \mathrm{SE}_{;} \mathrm{n}=5$ to 8 were significantly lower than the RCRol $(9.98 \pm 2.74$ (boreal individuals) and $3.31 \pm 0.44$ (subpolar individuals) at $0^{\circ} \mathrm{C}$. State 3 rates were significantly correlated with RCRol values ( $p<0.02)$, but the $r^{2}$ value did not exceed 0.09. State 4 ol rates were a major determinant $(\mathrm{p}=0.0001)$. The ADP/O ratio at the acclimation temperature of $11^{\circ} \mathrm{C}$ was $1.57 \pm 0.07$ in boreal animals and $1.67 \pm 0.11$ in White Sea lugworms, with no significant differences between populations and no significant effect of temperature (Fig. 4).

\section{Aerobic enzyme capacities}

CytOx activity ( $\mathrm{U} \mathrm{g}^{-1}$ fresh wt) was about 10 times higher in subpolar lugworms acclimated to $6^{\circ} \mathrm{C}$ than in boreal lugworms acclimated to $11^{\circ} \mathrm{C}$ (Fig. 5). A higher mitochondrial density in the subpolar worms would explain a higher enzyme content and activity, however, only by a factor of 2.4. It is unlikely that acclimation to $6^{\circ} \mathrm{C}$, compared with acclimation to $11^{\circ} \mathrm{C}$, would cause much further mitochondrial proliferation to explain this drastic difference. Much of the rise in activity beyond the factor of 2.4 may therefore result from quantitative changes within each mitochondrion as well as qualitative changes of the enzyme, as seen in a significant lowering of the $Q_{10}$ value and $E a$ for the oxidation of cytochrome $c$ in the White Sea lugworms (Table 1).

The method of enzyme extraction did not allow us to distinguish between the activity of cytosolic or mitochondrial NADP-dependent IDH, but the isozyme pattern following cold adaptation did not indicate a significant presence of cytosolic IDH (Hummel et al. 1997). The activity of the cytosolic enzyme seems to be negligible, comparable to the muscle tissue of different mammals (Plaut et al. 1983). Therefore, the observed differences in kinetic properties of IDH are likely to reflect different mitochondrial isozymes. The White Sea enzyme was more temperature-dependent than the North Sea enzyme, but due to the high variance, differences in $Q_{10}$ and Ea values were not significant (Table 1). However, ANCOVA comparison revealed significant differences between the populations. The higher thermal sensitivity of the White Sea enzyme resulted in significantly higher activities $\left(\mathrm{U} \mathrm{g} \mathrm{g}^{-1}\right.$ fresh wt) at elevated temperatures (Fig. 5).

\section{DISCUSSION}

\section{Latitudinal cold compensation of metabolic rate}

In an early metabolic study, Krüger (1964) found a temperature-independent rate of oxygen consumption 

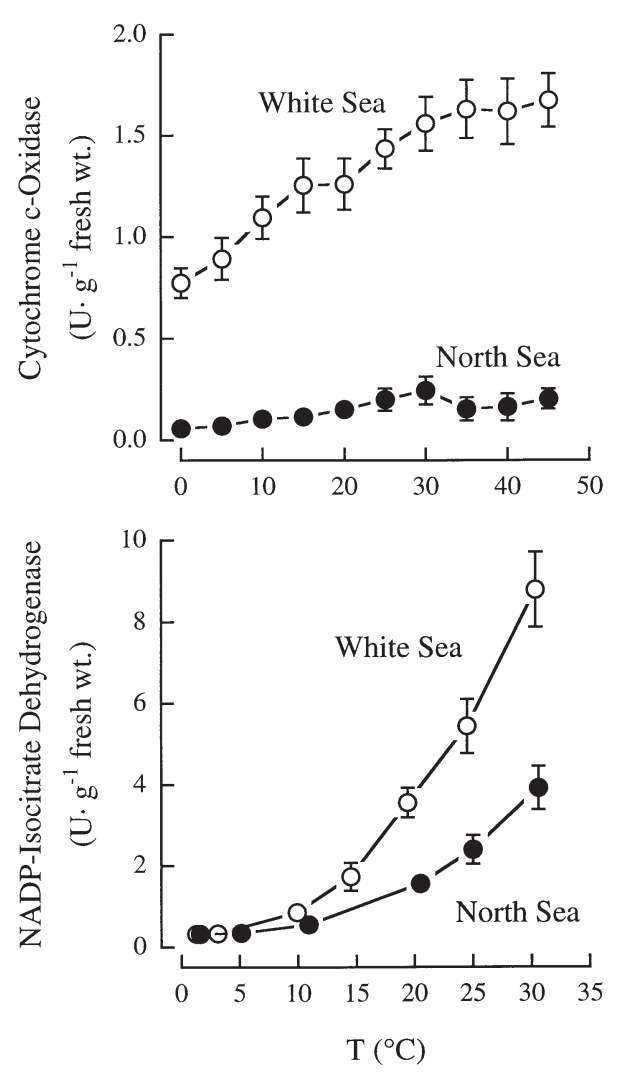

Fig. 5. Arenicola marina. Activities of cytochrome $c$-oxidase, the terminal oxidase of the respiratory chain, and of NADPdependent isocitrate dehydrogenase in the body-wall tissue of lugworms from the North and White Sea at various temperatures. Activities differed significantly between the 2 populations, and indicated a higher aerobic capacity in subpolar worms (CytOx) or different thermal sensitivities of IDH. Data are means $\pm \mathrm{SE}_{i} \mathrm{n}=5$ to 7 . For the respective Ea values see Table 1

in Arenicola marina from Helgoland, North Sea, during acute exposure to temperatures between 10 and $20^{\circ} \mathrm{C}$ after acclimation to $18^{\circ} \mathrm{C}$. Our data confirm that the change in metabolic rate is minimised within the range of thermal tolerance. However, this range can shift depending on acclimation temperature. North Sea lugworms acclimated to $11^{\circ} \mathrm{C}$ exhibited acute metabolic compensation between 10 and $15^{\circ} \mathrm{C}$, while this range was shifted to temperatures between 0 and $10^{\circ} \mathrm{C}$ in White Sea worms acclimated to lower temperatures. Compensatory mechanisms are, therefore, suitable to minimise short-term metabolic fluctuations within the window of tide-related and diurnal temperature changes in the respective habitats. The molecular mechanisms underlying acute temperature compensation of catabolism (energy production) are complex and have been discussed extensively in an early review by Hazel \& Prosser (1974). However, maintenance of catabolic rate requires constant rates of ATP consumption. Virtually nothing is known about how energy consumption is maintained within the range of thermal tolerance and how the range of thermal independence shifts with acclimation.

The concept of metabolic cold compensation implies that metabolic rates of organisms living under different temperature regimes are adjusted to similar values regardless of acclimatisation temperature (Hochachka \& Somero 2002). Although this pattern is not evident in stenothermal polar species (Clarke \& Johnston 1999, Peck \& Conway 2000, Pörtner et al. 2000) such a phenomenon can be seen in eurythermal lugworms. The metabolic rate of the subpolar worms at their acclimation temperature of $6^{\circ} \mathrm{C}$ was the same as that of North Sea worms acclimated to $11^{\circ} \mathrm{C}$ (Fig. 1). This resulted in temperature-specific rates of subpolar lugworms by (on average) 2.1 times above those of North Sea individuals for all temperatures investigated. Only in the temperature range of acute metabolic compensation (see above) was the oxygen consumption rate of White Sea worms only 1.4 times above those of North Sea worms. At $-3^{\circ} \mathrm{C}$ and at temperatures above $15^{\circ} \mathrm{C}$, temperature-specific rates of subpolar lugworms were significantly higher than those of North Sea lugworms. Maximal factorial differences were 2.8 at subzero temperatures and 3.3 at $25^{\circ} \mathrm{C}$. The higher mitochondrial density of White Sea worms (Table 2) may account for the rise in metabolic rate, in accordance with elevated metabolic expenditures expected in cold-adapted eurythermal compared to stenothermal species (Pörtner et al. 2000). The question arises as to whether the higher metabolic rate observed in White Sea lugworms is related to their lower acclimation temperature of $6^{\circ} \mathrm{C}$ compared with $11^{\circ} \mathrm{C}$ for the boreal worms. The discussion below will show that differences in aerobic capacity and mitochondrial density prevail even in worms at the same acclimation temperature. Permanent metabolic cold adaptation set at a genetic rather than phenotypic level is therefore suggested to distinguish the White Sea from the North Sea population.

\section{Thermal limits and mitochondrial oxygen demand}

In the lugworm Arenicola marina extreme temperatures elicit anaerobic metabolism, indicating the existence of both a high and a low critical temperature $\left(T \mathrm{C}_{i}\right.$ Sommer et al. 1997). At these TCS, aerobic scope is lost and energy demand cannot be met by adequate oxygen supply. Within the envelope of $T_{\mathrm{CS}}$, a narrower temperature window is set by limits to maximum aerobic scope (pejus temperatures: $T p$; Frederich \& Pörtner 2000). Both Tp and TC values are determined by the capacity of ventilation and circulation for adequate 
oxygen supply. Onset of limited aerobic scope appears as the first line of thermal sensitivity close to environmental temperature extremes (Zielinski \& Pörtner 1996, Pörtner 2001). However, latitudinal or seasonal temperature adaptation in A. marina causes a more or less parallel shift in both $T \mathrm{c}$ and (probably) $T \mathrm{p}$ values (Sommer et al. 1997). The present study indicates that the lower thermal limits found in the subpolar population depend upon the adjustment of mitochondrial density and capacity and are related to the latitudinal cline. This is the first time that increased mitochondrial volume densities have been observed in cold-adapted marine invertebrates, indicating that this adaptational feature is not restricted to fishes (e.g. Guderley \& Blier 1988, Archer \& Johnston 1991). On an evolutionary timescale, it must therefore reflect a rather ancient and fundamental mechanism.

Not only higher mitochondrial densities but also mitochondrial capacities were increased in muscle tissue of cold-adapted subpolar lugworms compared with boreal lugworms acclimated to the same temperature of $11^{\circ} \mathrm{C}$ (Fig. 2). Values of Ea for State 3 respiration were reduced in White Sea lugworms (Table 1). The main advantage of an increase in mitochondrial density and activity is an increase in aerobic capacity and increased amount of intracellular membrane lipids, which constitute an important pathway of intracellular oxygen transport (Sidell 1998). Energy production is improved, providing enough energy (e.g.) for ventilation and circulation (Pörtner 2001). The lower thermal limits shift downwards. This appears to be a prerequisite for the maintenance of high levels of motor activity at the subzero temperatures (Kolyakina 1980),

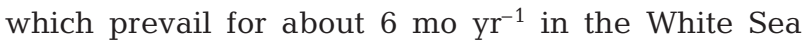
(Howland et al. 1999).

As a tradeoff in cold adaptation, the maintenance costs of ionic and proton gradients across each individual mitochondrial membrane have to be met. A rise in standard metabolism is the result of increasing mitochondrial densities, unless this process is compensated by a change in mitochondrial properties (Pörtner et al. 1998). This is not the case in the subpolar worms. The baseline idling of mitochondria, i.e. State $4 \mathrm{ol}$ respiration rate, mainly compensates for the effect of proton leaks (Brand \& Murphy 1987). In subpolar compared to boreal lugworms, the proton leakage rate in mitochondria, inferred from State 4 ol respiration rate, even increased at all temperatures (Fig. 2), possibly as a consequence or precondition for enhanced mitochondrial capacity. It is presently unclear whether the difference in proton leakage rate between the 2 populations is related to a difference in proton motive force (St-Pierre et al. 2000), to different activator concentrations (Cadenas et al. 2000), or to different membrane compositions (Brand et al. 1994, van de Vossenberg et al. 1999). Enhanced mitochondrial capacity and proton leakage as well as drastically increased activities of the membrane enzyme CytOx (see next subsection) suggest that different membrane properties are involved. Increased proton leakage rates (per mg mitochondrial protein) exacerbate the effect of elevated mitochondrial densities on the standard metabolic rate (Brand 1990, Brookes et al. 1998). This would further explain the elevated oxygen demand in White Sea lugworms at all temperatures. Consequently, the balance between the oxygen supply to the tissues and oxygen consumption during environmental warming is disturbed at lower temperatures in the subpolar than in the boreal population. As suggested earlier (Sommer et al. 1997), mitochondrial proliferation not only causes a downward shift in the low $T_{\mathrm{C}}$, but also a drop in the upper TCS.

\section{Adaptation of mitochondrial functions to eurythermal cold}

The 3- to 4-fold higher specific rates (per mg mitochondrial protein) in States 3,4 and 4ol respiration in mitochondria from subpolar lugworms are in line with similar findings by Tschischka et al. (2000) for Nereis pelagica and Arctica islandica, and appear to be a consequence of eurythermality (Pörtner et al. 2000). Evidently, mitochondrial coupling (RCR) is maintained regardless of maximum aerobic capacity. Since neither a dependence of the ADP/O ratio on temperature nor differences in the $\mathrm{ADP} / \mathrm{O}$ ratio between the 2 populations were found (Fig. 4), this ratio also seems to be independent of the maximum capacity of succinate oxidation. Obviously, these eurythermal worms can maintain mitochondrial phosphorylation at temperatures beyond $T \mathrm{c}$ values. In accordance with a hierarchy of thermal tolerance limits, a failure in the oxygen delivery system at the whole-organism level occurs prior to a failure in mitochondrial functions, thereby setting the critical thermal tolerance thresholds of the intact organism (Pörtner 2001).

A higher mitochondrial content ultimately implies a higher concentration of mitochondrial enzymes, like CytOx. Actually, compared with worms from the North Sea, we found a 10 times higher activity of CytOx in lugworms from the White Sea (Fig. 5). However, this rise was much higher than expected from the 2.4 times higher mitochondrial density and the somewhat lower acclimation temperature $\left(6\right.$ vs $11^{\circ} \mathrm{C}$ for the North Sea population). A fraction of the rise in activity may result from an increased expression of CytOx within each mitochondrion. Hardewig et al. (1999) showed that in the eelpout Zoarces viviparus mRNA levels of the 
nuclear encoded CytOx subunit IV increase strongly during cold adaptation. In addition, CytOx activity in cold-acclimated goldfish Carassius auratus was shown to rise through a modulation of activity and not enzyme quantity (Hazel \& Prosser 1974). The observation that the Ea of CytOx is significantly reduced in White Sea compared to North Sea specimens indicates that the latter phenomenon also occurs in lugworms. Wodtke (1981a,b) suggested that in cold-acclimated carp Cyprinus carpio the molar activity of CytOx is increased by changes in the phospholipid composition of mitochondrial membranes. Cold-acclimation considerably increases unsaturation of the neutral phosphatidylcholine, whereas it dramatically decreases unsaturation of the negatively charged cardiolipin, which constitutes a lipid shell (annulus) surrounding the oxidase within the native membrane. Changes in the membrane composition may also be responsible for the rise in CytOx activity and therewith the increased capacity and oxygen demand of individual mitochondria in White Sea compared with North Sea lugworms (Figs. 2 $\& 5)$. This would also be in line with the higher proton leakage rate in the subpolar worms (see foregoing subsection).

Activities of the mitochondrial NADP-dependent IDH were also enhanced in White Sea compared to North Sea lugworms. In Arenicola marina, the expression of different isozymes of NADP-dependent IDH shows a linear and highly significant correlation with the mean annual temperatures in the respective habitats (Hummel et al. 1997). Temperature may have a selective influence, since the functional properties of IDH differ in both populations (Fig. 5). The thermal dependence and activation energy of IDH was higher in cold-adapted White Sea lugworms (Table 1). This finding contradicts the paradigm that $E a$ values of enzymatic reactions are reduced during cold adaptation. Further examples exist which have recently been reviewed: e.g. high values of Ea appear to be typical for NADP-dependent IDH in cold-adapted animals (Pörtner et al. 2000). NADP-dependent IDH may play a role in the regulation of flux through the citric acid cycle (Urich 1990). This has recently been specified in that this enzyme may be a significant part of a futile substrate cycle that involves NAD- and NADP-dependent IDH and transhydrogenase, and accompanies the transport of protons into the mitochondrial matrix (Sazanov \& Jackson 1994). Our current view is that a rise in Ea under cold conditions may reflect a negative compensation for the rise in metabolic flux associated with mitochondrial proliferation. This substrate cycle may also regulate proton leakage rate in vivo (Sazanov \& Jackson 1994, Pörtner et al. 2000) and minimise the rise in oxygen demand in cold-adapted lugworms at temperatures around the acclimation temperature to 1.4 times, a lower value than would be expected from the 2.4 -fold increase in mitochondrial density.

\section{Conclusions and perspectives}

In lugworms from the White Sea, a shift of the low TC to a lower value is accompanied by an increase in aerobic capacity. This is effected by a higher mitochondrial density and an elevated oxidative capacity of individual mitochondria. In accordance with the general assumption that Ea values decrease in coldadapted animals, the Ea for the oxidation of cytochrome $c$ and for mitochondrial State 3 respiration at low temperatures were reduced in the subpolar population. This raised their capacity for aerobic energy production at low temperatures and the low critical temperature shifted to lower values.

At extreme temperatures, a drastic rise in oxygen consumption occurred in subpolar lugworms. The rise in aerobic metabolism correlates with an increase in the anaerobic metabolic rate and an improved ability to survive temperatures that are extreme in comparison to the ambient temperature regime (Sommer et al. 1997, Sommer \& Pörtner 1999). This indicates that energy-consuming processes may be involved in the mechanisms of improved thermal tolerance. However, the higher mitochondrial density contributes to the rise in standard metabolic rate seen in White Sea lugworms. A rise in mitochondrial proton leakage rate or, to a lesser extent, oxygen radical production could also be involved in the rise in oxygen consumption, especially during environmental warming. The latter processes would not contribute to ATP production (Brand et al. 1994). During environmental warming, a discrepancy between oxygen demand and supply emerges earlier in subpolar than in boreal lugworms. As a result, the high $T_{C}$ shifts to a lower value also. At normal habitat temperatures, a rise in the Ea for the decarboxylation of isocitrate in White Sea specimens may help to minimise the increase in the standard metabolic rate induced by mitochondrial proliferation. However, this process occurs at the expense of a greater thermal sensitivity of the metabolic rate and, thus, a lower $T_{\mathrm{C}}$ at higher temperatures.

Acknowledgements. Parts of this study were carried out at the White Sea Biological Station/Zoological Institute of the Russian Academy of Science in St. Petersburg, Russia. We are grateful for the excellent support of Dr. V. V. Fedjakov and Dr. A. A. Sukhotin and all the helpful hands at the station. Special thanks go to K. Beyer, Alfred Wegener Institute, for her help and introduction to electron microscopy techniques. 


\section{LITERATURE CITED}

Archer SD, Johnston IA (1991) Density of cristae and distribution of mitochondria in the slow muscle fibers of antarctic fish. Physiol Zool 64:242-258

Badyukov DD (1979) Sea level changes on the Soviet shores of the White, Baltic and Black Seas during the past 15 thousand years. Oceanology 19:177-181

Boyden CR (1972) Aerial respiration of the cockle Cerastoderma edule in relation to temperature. Comp Biochem Physiol A43:697-712

Brand MD (1990) The contribution of the leak of protons across the mitochondrial inner membrane to standard metabolic rate. J Theor Biol 145:267-286

Brand MD, Murphy MP (1987) Control of electron flux through the respiratory chain in mitochondria and cells. Biol Bull 62:141-193

Brand MD, Chien LF, Ainscow EK, Rolfe DF, Porter RK (1994) The causes and functions of mitochondrial proton leak. Biochim Biophys Acta 1187:132-139

Brookes PS, Buckingham JA, Tenreiro AM, Hulbert AJ, Brand MD (1998) The proton permeability of the inner membrane of liver mitochondria from ectothermic and endothermic vertebrates and from obese rats: correlations with standard metabolic rate and phospholipid fatty acid composition. Comp Biochem Physiol B 119:325-334

Cadenas S, Buckingham JA, St-Pierre J, Dickinson K, Jones RB, Brand MD (2000) AMP decreases the efficiency of skeletal-muscle mitochondria. Biochem J 351:307-311

Clarke A, Johnston NM (1999) Scaling of metabolic rate with body mass and temperature in teleost fish. J Anim Ecol 68: 893-905

Crockett EL, Sidell BD (1990) Some pathways of energy metabolism are cold adapted in antarctic fish. Physiol Zool 63:472-488

Dahlhoff E, Somero G (1993) Kinetic and structural adaptations of cytoplasmatic malate dehydrogenases of Eastern Pacific abalone (genus: Haliotis) from different thermal habitats: biochemical correlations of biogeographical patterning. J Exp Biol 185:137-150

Estabrook RW (1967) Mitochondrial respiratory control and the polarographic measurement of ADP:O ratios. In: Estabrook RW, Pullman ME (eds) Methods in enzymology, Vol 10. Academic Press, New York, p 41-47

Frederich M, Pörtner HO (2000) Cardiac and ventilatory performance at critical temperatures in the spider crab, Maja squinado (Decapoda). Am J Physiol 279:R1531-R1538

Gaebel K, Roots BI (1989) Stereological analysis of mitochondria from brains of temperature acclimated goldfish, Carassius auratus L (5 and $30^{\circ} \mathrm{C}$ ). J Therm Biol 14:187-190

Govberg LI (1974) Holocene molluscs of the White Sea. Oceanology 14:547-551

Guderley H (1990) Functional significance of metabolic responses to thermal acclimation in fish muscle. Am J Physiol 259:R245-R252

Guderley H (1998) Temperature and growth rates as modulators of the metabolic capacities of fish muscle. In: Pörtner HO, Playle RC (eds) Cold ocean physiology. Cambridge University Press, Cambridge, p 58-87

Guderley H, Blier P (1988) Thermal acclimation in fish: conservative and labile properties of swimming muscle. Can J Zool 66:1105-1115

Hand SC, Somero GM (1983) Energy metabolic pathways of hydrothermal vent animals: adaptation to food-rich and sulfide-rich deep-sea environment. Biol Bull 165:167-181

Hardewig I, van Dijk PLM, Moyes CD, Pörtner HO (1999) Temperature-dependent expression of cytochrome- $C$ oxi- dase in Antarctic and temperate fish. Am J Physiol 277: R508-R516

Hartmann-Schröder G (1971) Annelida, Borstenwürmer, Polychaeta. In: Dahl M, Peus F (eds) Die Tierwelt Deutschlands und der angrenzenden Meeresteile. VEB Gustav Fischer Verlag, Jena, p 445-448

Hazel JR, Prosser CL (1974) Molecular mechanisms of temperature compensation in poikilotherms. Physiol Rev 54: 620-677

Hochachka PW, Somero GN (2002) Biochemical adaptation. University Press, Oxford

Howland RJM, Pantiulin AN, Millward GE, Prego R (1999) The hydrography of the Chupa Estuary, White Sea, Russia. Estuar Coast Shelf Sci 48:1-12

Hummel H, Sommer A, Bogaards RH, Poertner HO (1997) Variation in genetic traits of the lugworm Arenicola marina: temperature related expression of mitochondrial allozymes? Mar Ecol Prog Ser 159:189-195

Johnston IA, Guderley H, Franklin CE, Crockford T, Kamunde C (1994) Are mitochondria subject to evolutionary temperature adaptation? J Exp Biol 195:293-306

Kolyakina NM (1980) The seasonal and age characteristics in the distribution of lugworm Arenicola marina (Polychaeta) in the Kislaya inlet of Kandalaksha Bay. Biology of the White Sea 5:77-92 (in Russian)

Kresze GB (1988) Methods for protein determination. In: Bergmeyer HU (ed) Methods of enzymatic analysis, Vol II. $\mathrm{VCH}$, Weinheim, p 86-88

Krüger F (1964) Versuche zur Abhängigkeit der Atmung von Arenicola marina (Annelides Polychaeta) von Größe und Temperatur. Helgol Wiss Meeresunters 10:28-63

Logue JA, de Vries AL, Fodor E, Cossins AR (2000) Lipid compositional correlates of temperature-adaptive interspecific differences in membrane physical structure. J Exp Biol 203:2105-2115

Miranda EJ, Hazel JR (1996) Temperature-induced changes in the transbilayer distribution of phosphatidylethanolamine in mitoblasts of rainbow trout (Oncorhynchus mykiss) liver. J Exp Zool 274:23-32

Nesis KN (1983) A hypothesis on the origin of Western and Eastern Arctic distribution areas of marine bottom animals. Biol Morya Vladivostok 5:3-13

Nickerson DM, Facey DE, Grossman GD (1989) Estimating physiological thresholds with continuous 2-phase regression. Physiol Zool 62:866-887

Noack S (1980) Statistische Auswertung von Meß- und Versuchsdaten mit Taschenrechner und Tischcomputer. Walter de Gruyter, Berlin

Peck LS, Conway LZ (2000) The myth of metabolic cold adaptation: oxygen consumption in stenothermal Antarctic bivalves. In: Harper E, Taylor JD, Crame JA (eds) Evolutionary biology of the bivalve. Special Publ No. 177. Geological Society, London, p 441-450

Plattner H, Zingsheim HP (1987) Elektronenmikroskopische Methodik in der Zell- und Molekularbiologie. Gustav Fischer Verlag, Stuttgart

Plaut WE, Cook M, Aogaichi T (1983) The subcellular location of isozymes of NADP-isocitrate dehydrogenase in tissue from pig, ox and rat. Biochem Biophys Acta 760:300-308

Pörtner HO (2001) Climate change and temperature dependent biogeography: oxygen limitation of thermal tolerance in animals. Naturwissenschaften 88:137-146

Pörtner HO, Hardewig I, Sartoris FJ, van Dijk PLM (1998) Energetic aspects of cold adaptation: critical temperatures in metabolic, ionic and acid-base regulation. In: Pörtner $\mathrm{HO}$, Playle RC (eds) Cold ocean physiology. Cambridge University Press, Cambridge, p 88-120 
Pörtner HO, Hardewig I, Peck LS (1999) Mitochondrial function and critical temperatures in the Antarctic bivalve Laternula elliptica. Comp Biochem Physiol A 124:179-189

Pörtner HO, van Dijk PLM, Hardewig I, Sommer A (2000) Levels of metabolic cold adaptation: tradeoffs in eurythermal and stenothermal ectotherms. In: Davison W, Howard Williams C, Broady P (eds) Antarctic ecosystems: models for wider ecological understanding. Caxton Press, Christchurch, New Zealand, p 109-122

Prandle D, Lane A (1995) Stability of the annual temperature cycles in shelf seas. J Therm Biol 20:110-120

Ressel SJ (2001) Ultrastructural design of anuran muscles used for call production in relation to the thermal environment of a species. J Exp Biol 204(8):1445-1457

Reynolds ES (1963) The use of lead citrate at high $\mathrm{pH}$ as an electron-opaque stain in electron microscopy. J Cell Biol $17: 208$

Sazanov LA, Jackson JB (1994) Proton-translocating transhydrogenase and NAD and NADP-linked isocitrate dehydrogenase operate in a sustrate cycle which contributes to fine regulation of the tricarboxylic acid cycle activity in mitochondria. FEBS Lett 344:109-116

Schroff G, Schöttler U (1977) Anaerobic reduction of fumarat in the body-wall musculature of Arenicola marina (Polychaeta). J Comp Physiol B Biochem 116:325-336

Segal IH (1976) Biochemical calculations. John Wiley \& Sons, New York

Sidell DB (1998) Intracellular oxygen diffusion: the roles of myoglobin and lipid at cold body temperature. J Exp Biol 201:1119-1127

Sisson J, Sidell BD (1987) Effect of thermal acclimation on recruitment of muscle fibers in striped bass. Physiol Zool 60:310-320

Sommer A (1998) Temperature adaptation in the polychaete worm Arenicola marina (L.). Mechanisms and limitations. Ber Polarforsch 285:1-71

Sommer A, Pörtner HO (1999) Exposure of Arenicola marina (L.) to extreme temperatures: adaptive flexibility of a boreal and a subpolar population. Mar Ecol Prog Ser 181: $215-226$

Sommer A, Klein B, Pörtner HO (1997) Temperature induced anaerobiosis in two populations of the polychaete worm Arenicola marina (L.). J Comp Physiol B Biochem 167: 25-35

St-Pierre J, Charest PM, Guderley H (1998) Relative contribution of quantitative and qualitative changes in mitochondria to metabolic compensation during seasonal acclimation of rainbow trout Oncorhynchus mykiss. J Exp Biol 201:2961-2970

St-Pierre J, Brand MD, Boutilier RG (2000) The effect of meta-

Editorial responsibility: Otto Kinne (Editor),

Oldendorf/Luhe, Germany bolic depression on proton leak rate in mitochondria from hibernating frogs. J Exp Biol 203:1469-1476

Sugden PH, Newsholme EA (1975) Activities of citrate synthase, NAD+-linked and NADP+-linked isocitrate dehydrogenases, glutamate dehydrogenase, aspartate aminotransferase and alanine aminotransferase in nervous tissues from vertebrates and invertebrates. Biochem J 150: 105-111

Tschischka K, Abele D, Pörtner HO (2000) Mitochondrial oxyconformity and cold adaptation in the polychaete Nereis pelagica and the bivalve Arctica islandica from the Baltic and White Seas. J Exp Biol 203:3355-3368

Urich K (1990) Vergleichende Biochemie der Tiere. Gustav Fischer Verlag, Stuttgart

van Dam K, Wiechmann AHCA (1979) Respiratory control and oxidative phosphorylation measurements in mitochondria. In: Fleischer S, Packer L (eds) Methods in enzymology, Vol LV. Academic Press, New York, p 225-229

van de Vossenberg JLCM, Driessen AJM, da Costa MS, Konings WN (1999) Homeostasis of the membrane proton permeability in Bacillus subtilis grown at different temperatures. Biochim Biophys Acta 1419:97-104

Vetter RA, Buchholz F (1997) Catalytic properties of two pyruvat kinase isoforms in nordic krill, Meganyctiphanes norvegica, with respect to seasonal temperature adaptation. Comp Biochem Physiol A 116:1-10

Wesenberg-Lund E (1953) The zoology of East Greenland, Vol 122, No. 3. CA Reitzel Forlag, Kopenhagen

Wodtke E (1981a) Temperature adaptation of biological membranes. The effects of acclimation temperature on the unsaturation of the main neutral and charged phospholipids in mitochondrial membranes of the carp (Cyprinus carpio L.). Biochim Biophys Acta 640:698-709

Wodtke E (1981b) Temperature adaptation of biological membranes: compensation of the molar activity of cytochrome $c$ oxidase in the mitochondrial energy-transducing membrane during thermal acclimation of the carp (Cyprinus carpio L.). Biochim Biophys Acta 640:710-720

Wolff WJ (ed) (1983) Ecology of the Wadden Sea, Vol 1, Chapter 2: Hydrography. AA Balkema, Rotterdam

Yeager DP, Ultsch GR (1989) Physiological regulation and conformation: a BASIC program for the determination of critical points. Physiol Zool 62:888-907

Zenkevitch L (1963) Biology of the Seas of the U.S.S.R. George Allen \& Unwin, London

Zielinski S, Pörtner HO (1996) Energy metabolism and ATP free-energy change of the intertidal worm Sipunculus nudus below a critical temperature. J Comp Physiol B Biochem 166:492-500

Submitted: October 25, 2001; Accepted: May 17, 2002

Proofs received from author(s): August 22, 2002 